\title{
Occlusion of the Ascending Pharyngeal Artery During Carotid Artery Surgery: Importance and Technique
}

\author{
Karotis Arter Cerrabisinde Asendan Faringeal Arter Tıkanıklı̆̆ı: \\ Önem ve Teknik
}

Katsuya UMEOKA ${ }^{1}$, Takayuki MIZUNARI ${ }^{1}$, Yasuo MURAI ${ }^{2}$, Shiro KOBAYASHI ${ }^{1}$, Akio MORITA²

${ }^{1}$ Chiba-Hokusou Hospital, Nippon Medical School, Department of Neurosurgery, 1715 Kamagari, Inzai City, Chiba, Japan ${ }^{2}$ Nippon Medical School, Department of Neurosurgery, 1-1-5 Sendagi, Bunkyo-ku, Tokyo, 113-8603, Japan

Corresponding Author: Katsuya UMEOKA / E-mail: katsuya@nms.ac.jp

\begin{abstract}
AIM: In surgeries involving clamping, opening and repairing the carotid artery such as carotid endarterectomy (CEA) and proximal anastomosis at radial artery (RA) grafting, back-bleeding, often due to insufficient occlusion of the ascending pharyngeal artery (APA), must be avoided. In $96 \%$ of cases the APA originates at the dorsal side of the external carotid artery, while in $2 \%$ each it arises at the carotid bifurcation or the internal carotid artery. We developed a method to prevent back-bleeding from the APA irrespective of its origin.

MATERIAL and METHODS: For CEA we dissect the internal carotid artery and clamp the APA and the external carotid artery together. For RA grafting we dissect the external carotid artery and if the APA branches directly from this vessel, the APA is clamped directly.

RESULTS: We used our new surgical technique in 54 cases (22 CEA and 32 RA grafts) and encountered no major back-bleeding. CONCLUSION: We consider this method to be simple and useful for improving the safety and success of carotid artery surgeries. KEYWORDS: Carotid endarterectomy, Radial artery grafting, Ascending pharyngeal artery, Back-bleeding
\end{abstract}

öz

AMAÇ: Karotid endarterektomi (CEA) ve radial arter (RA) greftte proksimal anastomoz gibi karotis arteri klempleme, açma ve onarmayı içeren ameliyatlarda genellikle asendan faringeal arter (APA)'ın yetersiz kapatılmasından kaynaklanan geri kanamadan kaçınılmalıdır. APA olguların \%96'sında eksternal karotid arterin dorsal tarafından kaynaklanmakta ve \% 2'sinde, karotid bifurkasyon veya internal karotid arterden köken almaktadır. Biz kökeni ne olursa olsun APA'dan kaynaklanan geri kanamayı önlemek için bir yöntem geliştirdik.

YÖNTEM ve GEREÇLER: CEA için internal karotid arterin diseksiyonunu yapıp APA ile eksternal karotid arteri birbirine klempliyoruz. RA greftleme için dış karotid arterin diseksiyonunu yapıyoruz ve APA doğrudan bu damardan köken alıyorsa APA'yı doğrudan klempliyoruz.

BULGULAR: Bu yeni cerrahi tekniğimizi 54 olguda (22 CEA ve 32 RA grefti) kullandık ve önemli bir geri kanama ile karşılaşmadık.

SONUÇ: Bu yöntemin karotid arter ameliyatlarının güvenliğini ve başarısını artırmak için basit ve faydalı olduğunu düşünüyoruz.

ANAHTAR SÖZCÜKLER: Karotid endarterektomi, Radial arter greftleme, Asendan faringeal arter, Geri kanama

\section{INTRODUCTION}

Complications encountered after carotid endarterectomy (CEA) and proximal anastomosis at radial artery (RA) grafting include re-bleeding from the sutured artery, cerebral infarction due to thrombus formation at the suture site, and arterial occlusion. To avoid such complications and to prevent back-bleeding, the surgical field should be dry. However, if the ascending pharyngeal artery (APA) arises between areas of the arteriotomy, it is often difficult to stop back-bleeding completely. Therefore, for appropriate dissection of the carotid artery and placement of the cross-clamp, the pattern of APA branching off the carotid arteries must be known. Considering variations in the origin of the APA we investigated sites suitable for dissection in patients undergoing CEA or RA grafting.

\section{Surgical Technique}

All patients were operated under general endotracheal anesthesia with full cardiovascular monitoring. To expose the carotid arteries we first placed a longitudinal neck incision. Then the upper plane of the carotid sheath surrounding the common carotid artery was cut with scissors and the other planes of the carotid sheath were separated with scissors from the common-, external-, and internal carotid artery. After dissecting each artery the arterial flow was clamped and the artery was cut. Back-bleeding from the APA occurs when its origin is located between the site of clamping and the incision site.

For CEA, the common-, internal-, and external carotid artery are clamped and the carotid artery is opened from the 
common carotid artery toward the internal carotid artery. For proximal anastomosis at RA grafting, the external carotid artery is clamped at the site just distal to the common carotid artery bifurcation and at the site distal to the anastomosis and then the external carotid artery is opened. To obtain an adequate surgical field without eliciting back-bleeding after incising the blood vessel, the site of origin of the APA must be identified.

While the APA usually originates from the dorsal side of the external carotid artery, Hayashi et al. (1) reported that $2 \%$ arose from the carotid bifurcation and another $2 \%$ from the internal carotid artery. To prevent back-bleeding from the APA we developed a new surgical method. For CEA, dissection is performed between the internal carotid artery and the APA located in connective tissue between the carotid arteries, and the external carotid artery is cross-clamped. Dissection at this level and clamping of the internal carotid artery prevents back-bleeding from the APA. In RA grafting the external carotid artery is dissected and if the APA originates from the external carotid artery it is clamped directly.

\section{Patients}

Between January 2009 and February 2013, 22 patients (20 males, 2 females) ranging in age from 37 to 77years (mean $69.6 \pm 11.4$ years), underwent CEA and 32 (10 males, 22 females) also ranging from 39 to 76 years (mean $67.6 \pm$ 9.5 years), underwent RA grafting using our new method. While at CEA, the APA located in connective tissue between the carotid arteries was not detected, cross-clamping with the external carotid artery prevented back-bleeding from the APA. At RA grafting, some arteries branching from the external carotid artery were identified and clamped directly. Our surgical technique yielded an adequate surgical field and avoided back-bleeding from the APA (Figures $1 A, B ; 2 A, B$ ).

\section{DISCUSSION}

The necessity and usefulness of CEA and RA grafting have been documented. Complications after these procedures such as cerebral infarcts due to thrombus formation and postoperative bleeding may be partly attributable to insufficient clarity of the surgical field and to back-bleeding at the suture site $(2,3)$. Back-bleeding into the surgical field alerts to inadequate blockage of a branch from the external carotid artery. While in most cases the APA arises at the back of the external carotid artery near the common carotid artery bifurcation, its origin and configuration may vary and it may originate at the internal carotid artery. In their post-mortem study Hayashi et al. (1) found that $2 \%$ of APA arose from the carotid bifurcation and another $2 \%$ from the internal carotid artery.

To prevent back-bleeding during arteriotomy and repair, the branching pattern of the APA must be recognized. If the APA branches between the clamping sites, the unclamped APA wills back-bleed. At CEA the internal carotid artery is clamped and cut. If the APA branches off this vessel, the branch arising between the arterial portions is affected by the arteriotomy. Therefore, to obtain a clear surgical field without back-bleeding from the APA, it must be clamped. However, its origin may be the carotid bifurcation or the internal carotid artery. To avoid back-bleeding irrespective of the APA origin we developed the method described herein. In patients treated by CEA, we place the dissection at the level

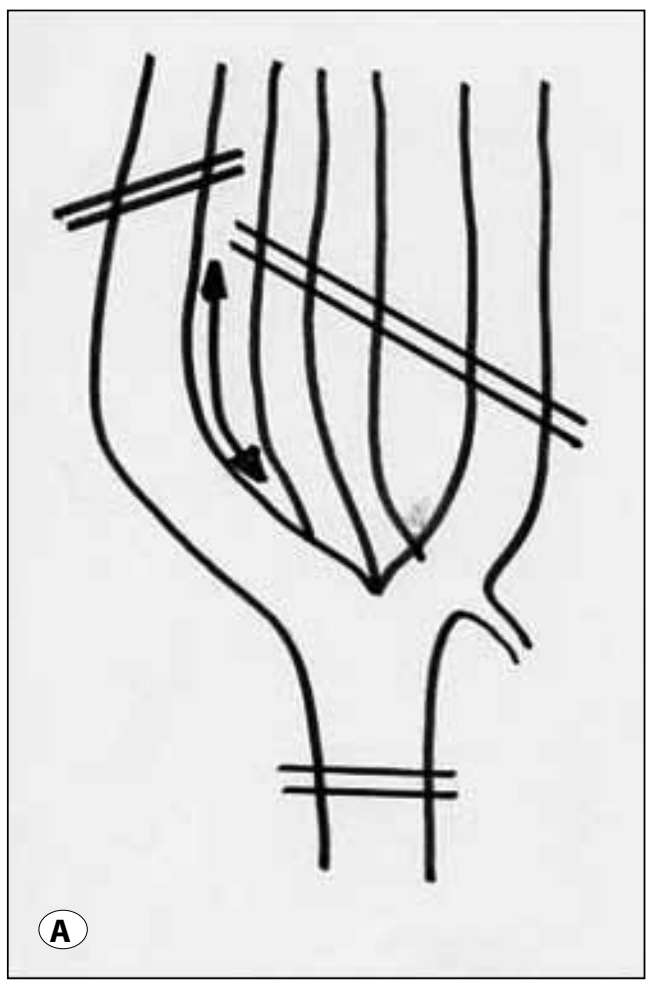

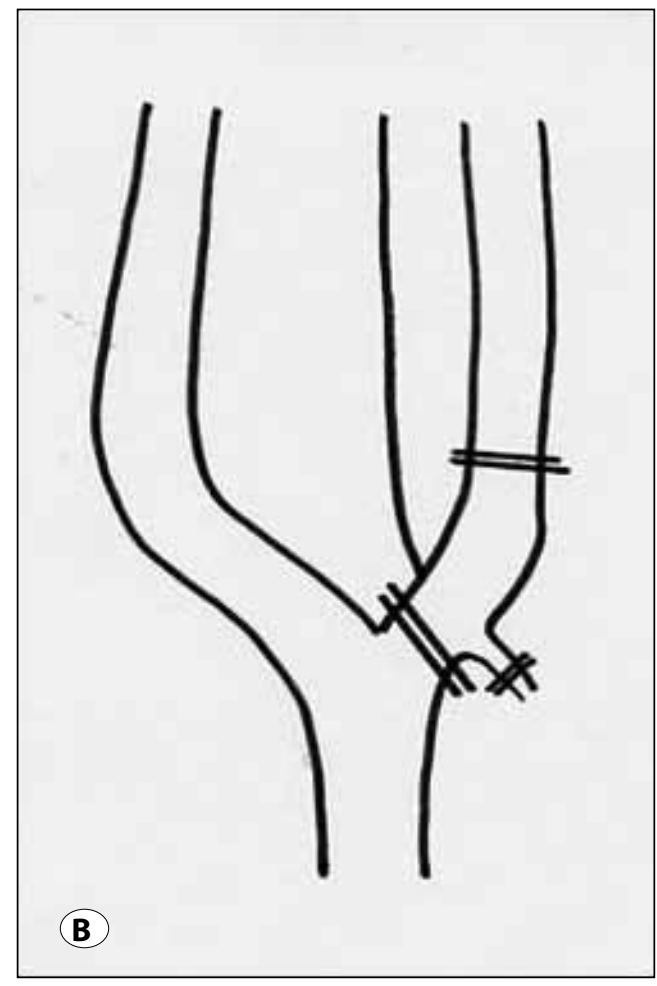

Figure 1: A) For CEA the dissection is performed on the internal carotid artery side. The ascending pharyngeal artery (APA) and the external carotid artery are clamped together when the APA originates at the external carotid artery, the carotid bifurcation, or the internal carotid artery.

B) For RA grafting the dissection is performed on the external carotid artery side. The APA is clamped if it branches directly off the external carotid artery. Double lines indicate the clamping sites. 

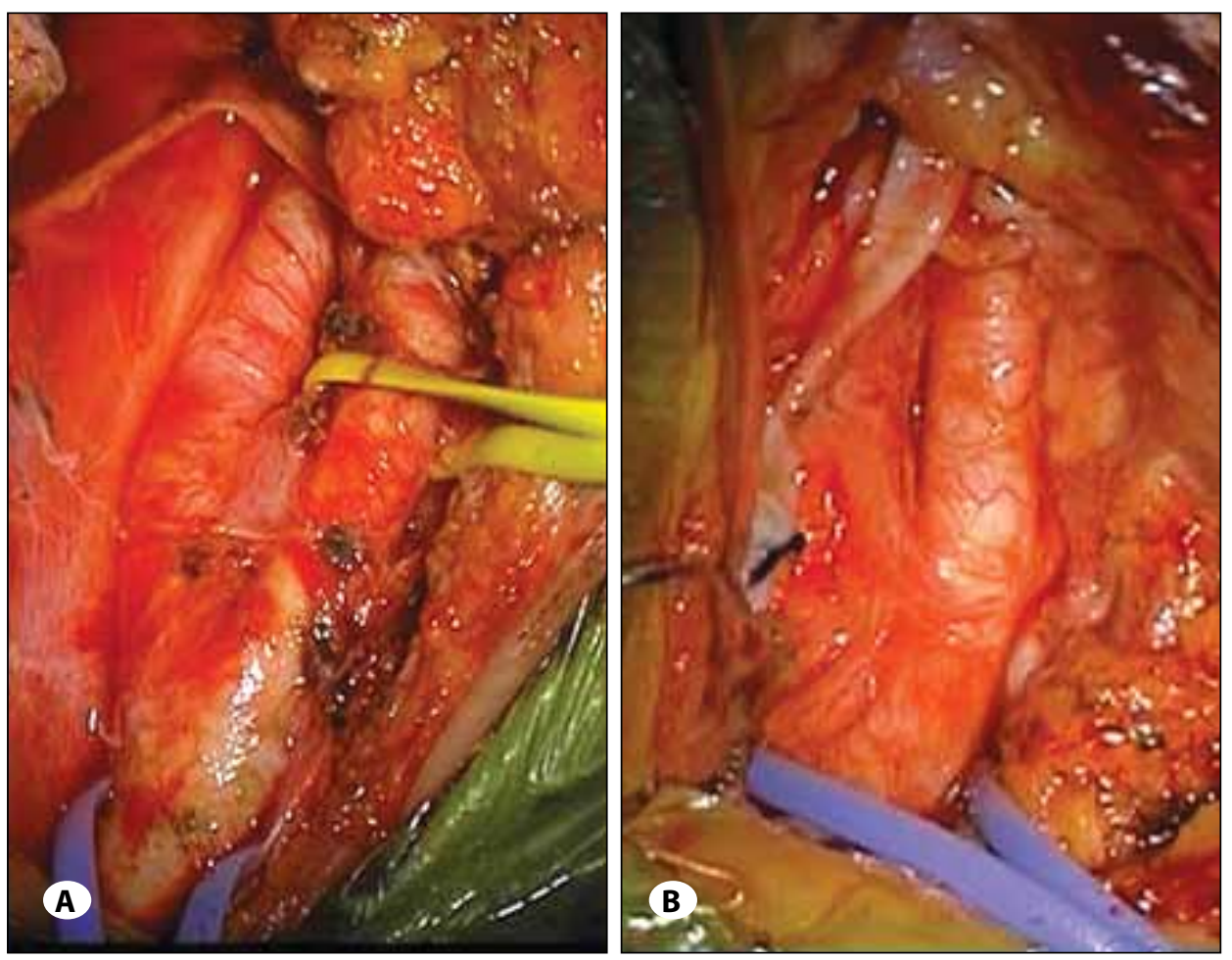

Figure 2: Intraoperative photographs showing the side of dissection. A) For CEA dissection is on the internal carotid artery side. B) For RA grafting dissection is on the external carotid artery side.

of the internal carotid artery and cross-clamp the APA and the external carotid artery. In cases where the APA branches off the external carotid artery it is clamped directly.

\section{CONCLUSION}

To avoid back-bleeding at CEA and RA grafting the sites of origin of the APA must be known for proper clamping and dissection.

\section{ACKNOWLEDGMENTS}

The authors have already submitted the self-reported potential COI disclosure of the Japan Neurosurgical Society.

\section{REFERENCES}

1. Hayashi N, Hori E, Ohtani Y, Ohtani O, Kuwayama N, Endo S: Surgical anatomy of the cervical carotid artery for carotid endarterectomy. Neurol Med Chir (Tokyo) 45(1):25-29,2005 discussion 30

2. McCrory DC, Goldstein LB, Samsa GP, Oddone EZ, Landsman PB, Moore WS, Matchar DB: Predicting complications of carotid endarterectomy. Stroke Sept 24(9):1285-1291,1993

3. Rothwell PM, Slattery J, Warlow CP: A systematic review of the risks of stroke and death due to endarterectomy for symptomatic carotid stenosis. Stroke 27(2):260-265,1996 